\title{
Systematic Carding of Modern Pre-school Education View
}

\author{
Zhang Ling \\ Education College of Yunnan Open University \\ Kunming, Yunnan 650500 \\ E-mail: 329785240@qq.com
}

\begin{abstract}
There are many views of pre-school education that have formed their own words, which are intersecting or complementary, complicated and expressed in different ways. How to combine various expressions to form a systematic view of pre-school education? From the facts of the pre-school education logic to grasp the core and basic problems of pre-school education, and form a pre-school education view of essence, value, practice and quality concepts, it is a feasible way to systematically master the concept of modern pre-school education.
\end{abstract}

Keywords—pre-school education view, systematic carding

\section{INTRODUCTION}

There are many views of pre-school education that have formed their own words, which are intersecting or complementary, complicated and expressed in different ways. How to combine various expressions to form a systematic view of pre-school education? From the facts of the pre-school education logic to grasp the core and basic problems of preschool education, and form a pre-school education view of essence, value, practice and quality concepts, it is a feasible way to systematically master the concept of modern preschool education.

\section{TO SySTEMATICALLY UNDERSTAND THE NECESSITY} AND FEASIBILITy OF MOdERN PRE-SCHOOL EdUCATION VIEW

\section{A. There are many views of pre-school education, which are not systematic and conducive to learn.}

Reference to many pre-school education teaching materials on the market, which analyzed pre-school education based on the contemporary concepts on children, these views are incomplete, or lack of depth, or without absorbing the advantages. At the same time, students and teachers who have obtained the textbooks cannot systematically grasp relevant theory, which is very detrimental to teachers' teaching and students' learning.

Reasons for this situation is that general education refers to the people's concept of education as well as the relationship between education and other things, the general aspects of education concept is diverse, scattered, and often explain education with education, lack of depth of expression, and is useless for people to understand education in depth. Preschool education, as a branch of education, also has such problems. At the same time, education is in the stage of rapid development, and the evolution of new and old ideas is more complicated.

In a word, it is necessary to systematically card the views of pre-school education.

\section{B. Enlightenment from the Narrow Sense of Education}

Professor Sun Miantao tries to systematize the educational concept in his article Thinking about Education Concept, puts forward to grasp the educational concept from the narrow educational concept. "There are four aspects to understanding the fundamental problem of education. One is the question of what education is, two is the role of education, three is how to play the role of education, four is the result of education. The understanding of what education is formed the essence concept of education, the understanding of the role of education formed education Value, the understanding of how to play the role of education formed the practical concept of education, and the understanding of result of education formed quality concept of education." [1] The essence, Value, practice and quality of pre-school education constitute the factual logic of pre-school education.

In pre-school education, the narrow educational concept can be profound and relatively comprehensive and is a feasible way to systematically understand pre-school education concept.

Sun Miantao professor compared the traditional education with the modern education in Practical Research of Education Ought to be Logic, the results of the analysis is: the essence concept of modern education emphasizes "Education is a social process of cultivating people.", the Value concept of modern education emphasizes the "It services human and society development. ", the practice concept of modern education emphasizes 'Direct intervention is combined with guidance services; Strict management is combined with relaxation and harmony.”, the quality concept of modern education emphasizes "To cultivate people with subjective characteristics.". [2] These connotations are consistent with the modern concept of pre-school education. 


\section{Systematic Carding of Modern Pre-SchoOl EduCATION VieWs}

The following conclusions can be drawn from the in-depth analysis of pre-school education concept from the perspective of narrow educational concept.

\section{A. The Essence Concept of Pre-school Education}

When people realize that children are human beings and should have all basic human rights, people's concept is undergoing some transformation: children are not only the object of legal protection, but also the subject of rights. From the only responsibility of parents to protect children to the obligation of the state and society to protect children; From "raising children to" to " serve children to become"; Children are independent individuals, natural beings and deserve a happy childhood; Childhood has its unique and irreplaceable value, Children are the father of adults, child is the father of adult, adult needs to learn from child. Children are capable subjects, and adults should respect them and provide them with appropriate opportunities.

It is shown that the essence of education is to cultivate people, cultivate real children, respect and meet the needs of children's development.

Contemporary concepts on children bring pre-school education idea essentially change, mainly reflected in the change of the degree of respect, from without respect and lack of adequate respect to respect and fully respect children, forming the characteristics of understand children, respect children, and take children as the main body. It can be roughly summarized into the following aspects:

1) The essence concept of pre-school education is based on the development of modern science and technology

Swiss educator Pestalozzi attaches importance to human nature and proposes to develop children's natural ability according to children's physical and mental characteristics, firstly advocated Psychologize of Education and Teaching. German educator Herbart is the most important representative of Psychological Movement of Education. The rapid rise and development of observational studies of children since the 1880s suggest that psychology has matured to the point of shifting research from adults to children. The Spirit of Children by German physiologist and psychologist Pryor in 1882 marked the establishment of scientific child psychology. The development of modern science and technology, especially the development of physiology, brain science and psychology, has given people a deeper understanding of children's characteristics and abilities.

Pre-school education can lead children's development and promote their development, but it must follow the law of children's physical and mental de velopment. Modern scientific educational concept is based on scientific child psychology, pedagogy and other disciplines.
2) The essence concept of pre-school education treats children from the perspective of development, believing that children are capable subjects

Dewey believed that people have a capacity for development in childhood. "Man has the capacity or possibility to learn anything because he has a particularly long infancy." [3] Longer childhood is stably hiding the possibility of learning complex skills. Scientific education concept believe that children are capable of main body, the essence of the children is positive, they like and need to explore and study instinctively, their cognitive structure and knowledge skills are constructed in the interaction process of self and objective environment. The process of independent learning is the process of children constantly encountering problems and solving problems. We want children to be a wise solution maker, this is the best way to let him have a lot of chance to do what he is willing to do and interested in, to solve problems that they want to, to gain development of wisdom independently.

3) The essence concept of pre-school education advocates that education makes children feel happy

The fundamental purpose of children's education is the development of children. Pleasure is not the development itself, but the expression of children's development needs to be satisfied. With this attribute, it is the real quality of children education. Most of children's education goals should make children feel happy in the process of activity. Without pleasure, it means that children will not have real interest in learning, real active activities, and real development.

4) The essence concept of pre-school education Value and respect children's right to play games

The game is the individual initiative, spontaneous, pleasantly free activity. Finland scholar Hu Yiqing said in People: The Player --- the Research of the Factors of Game in Culture, the game is defined as a free activity that completely and consciously excluded "daily life", "not really", but at the same time strongly attracting players. Games have several main features: fun and enjoyable; without external goals; spontaneous and autonomous; requiring the active participation of the players. The human individual all grows up from the game, the game is necessary for human growth and development.

Games are more closely related to children. People call games "children's work," and children need them as much as safety and food. At the same time, children are fond of games, which is the nature of children. Games are children's lives. Children live in a world of games. Children learn about the world around them through games. Children develop themselves through games. Games are an internal need of children's development process, and they are also children's sacred rights.

5) The essence concept of pre-school education respects individual differences

In the development of children's personality, some characteristics are consistent with the general character, and some features are ahead of or behind the general character in the development speed. In addition, every child has distinct 
personality differences, and there are no identical children of the same age. The scientific educational concept says teaching according to their aptitude, breaks the unified management mode of "walking together", and allows teachers to carry out their work creatively according to the class situation. Break the closed operation mode, fully reflect the open principle and give children the opportunity to develop their own independent activities in all aspects of kindergarten life.

\section{B. The Value Concept of Pre-school Education}

Pre-school education not only serves the development of children, but also serves the development of society.

The Value of pre-school education refer to satisfying and being satisfied relationship between needs of decision-makers, designers, implementers, learners and attributes of pre-school education. "The subjects of pre-school education value relations include society (human beings, countries, communities, etc.) and indi viduals (children, teachers, parents, etc.). The needs of these subjects are diversified and multilayered." [4] However, they have a unified point, that is, the development of pre-school children. Therefore, the primary and fundamental Value of pre-school education is its Value to the development of pre-school children.

\section{1) Value at the Child Level}

As the main body, children's core need is development. The development needs of children are various, and different children have different development tendencies and needs. The main needs of children include three aspects:

\section{a) Physical Needs}

For children, the needs of the body take the first place, requiring the combination of kindergarten preservation and education, as well as the importance of health and education.

Physical needs are particularly evident and prominent in childhood. Children have special requirements in nutrition, sports, sleep and other aspects. Different from other education institutions, it is the responsibility of kindergarten to provide food, sleep and other living conditions for children. Due to the low level of physical and mental development of children, children lack the necessary skills to take care of themselves, such as eating, wearing clothes and shoes, toilet, and need adult's help and guidance. The satisfaction of children's physical needs is the premise and foundation of other needs. In addition, special attention must be paid to children with special physical needs, especially disabled children. Reasonable pre-school education not only guide children to understand and meet the needs of the front body, also should help children to understand the overall body need, to some extent and help children to master the basic skills to meet those needs.

\section{b) Social and Psychological Needs}

Children's good social and psychological experience should be an important part of children's education and permeate the whole education.

The general social psychological needs are acceptance, approval, belonging, success and safety. These needs are personal, but they must be acquired in relationships with others. For children, the need for safety and acceptance is an important need. Western scholars call for "unconditional acceptance of children". Of course, there are certain differences in social and psychological needs among children. Therefore, we should focus on the social psychological needs of individual children, especially those talented, creative, emotional disorder, slightly dull and seriously retarded children. These needs of children should be reflected in specific curricula and implemented in specific curricula. The social psychological needs in the early childhood are the basis of the more complex social psychological needs in the future. The satisfaction of social psychological needs in early childhood is of great significance to the generation and satisfaction of social psychological needs in the future.

\section{c) Development Needs}

Today's pre-school education is the foundation for tomorrow's development. The pre-school education target should not only be limited to children's performance in the pre-school three years, it should foretell in the longer period after pre-school education. Children get education opportunity, not equal to children get development; The progress of children in a certain aspect does not mean that children can obtain long-term development in the future. Children's development needs for education are multifaceted and comprehensive.

\section{2) National Level Value}

Countries, group, class as the main body, its core need to be a cultural inheritance, concept penetration, namely inheritance and penetration need, namely through the course, the specific culture is passed to the education object, through the course infiltration of specific countries, group, class interests and ideas, make the educatee obtain good development at all level courses, in turn, become members of society expected by nation, group, class, the development of individual and nation, group, class needs to be consistent. Preschool education has the same value, but it has been around for a long time.

\section{3) Teacher Level Value}

As the main body, teachers' core needs are to create and meet challenges, achieve and develop. Teachers through the implementation of curriculum, pay a creative labor and accept the challenge of the difficult and teacher's intelligence work, fully utilizing the existing knowledge, and to make progress in the challenge for development.

\section{4) Parental Level value}

Parents as the body of the pre-school education value, its core need is the need of parenting, namely through education to cultivate children to become talents, and hope that through education permeate some of their idea, especially moral value. Parents of different social backgrounds and classes may have different needs for education, and there may be conflicts between some needs.

\section{Practice Concept of Pre-school Education}

\section{1) Scientific Curriculum Setting}

Curriculum is one of the most important and complex problems in education. The definition of curriculum varies 
from one dimension to another. Curriculum research and reform has a long history, from a practical curriculum theory, the structuralism theory of curriculum, the humanistic curriculum theory, the postmodern curriculum theory, in the step by step exploration, finally evolves to scientific. The development of kindergarten curriculum in China has also gone through the process of production, exploration, reform and improvement.

\section{2) Life-oriented Education Content}

Scientific education content should reflect children's life, for the sake of children's life, but also make use of children's life. "Life is development, and to develop, to grow, to live." says Dewey. He emphasized that the education process is a social process and a life process.

\section{3) Activity-oriented Education Formal}

Piaget's theory of cognitive development emphasizes the importance of main body activities and believes that learning is an active process of construction, and children are the main body of learning. The process of children's knowledge acquisition is the process of children's active participation in activities and continuous construction and improvement of cognitive structure. The concept of scientific education advocates that education should be carried out in an active way and requires multi-sensory participation in activities, which is moderately challenging and can trigger the interaction between children and the outside world.

\section{4) Ecological Education Environment}

The so-called ecological environment refers to the environment suitable for children's growth and life, in which various ecological factors promote each other and de velop in a coordinated way. The ecological environment requires the environment to be children's own, changing and omnidirectional.

\section{Quality Concept Pre-school Education}

There are many levels and angles to judge the quality of pre-school education. Education process itself, children's performance in education process, teachers' quality, education effect and so on, can all be judged by quality. However, the essence of pre-school education is to cultivate people and cultivate children in a real sense. From this essence, the evaluation of pre-school education quality can be summarized as the evaluation of education object -- children's quality. Different historical periods require different properties of education objects. The requirements of contemporary scientific education concept on children's quality can be summarized as follows:

\section{1) People with All-round Development}

Children's physical and mental development is an organic whole, and its development is the integrated development of body, cognition, emotion, society and personality. In 1996, the State Education Commission issued the Kindergarten Work Regulations, specified in article 3: 'Kindergarten's mission is: to implement the principle of combining conservation and education, carry out education in all-round development for children's body, intelligence, moral, beauty, and promote the harmonious development of body and mind." "Barrel Theory" also tells us that more than one side of the development of the children is to form a whole board, if a board short and thin, so the bucket holds very little water, and even cannot hold water.

\section{2) People with Harmonious Development}

Some people say that the fundamental purpose of education is not only to promote the development of children, but also to enable children to have a complete and happy life. The development of children is not only comprehensive, but also harmonious, balanced and pleasant. Only such development can be sustained and constant.

\section{3) People with Main Character}

Modern education places more and more emphasis on respecting children's subjectivity and promoting their development of subjectivity, activity and creativity.

Rousseau put forward the important proposition of "Treat Children as Children", emphasizing that education should be carried out in a natural and harmonious way based on the nature of children, to establish the dominant position of children in the process of education. Piaget's theory of cognitive development holds that learning is a process of active construction, and children are the subject of learning. Dewey, Flaubert, Montessori and other educators have all seen the importance of children's subjectivity. It is necessary for social development to establish children's main body status, stimulate children's inner initiative and cultivate creative children.

\section{4) People with Personality}

Traditional education in China tends to develop people's sociality, while education in western countries tends to develop people's personality. Currently, China's education sector has noticed that "education, which focuses on developing sociality but ignores developing personality”, cannot meet the needs of China's reform and opening-up. This kind of "social standard" education's error is that treat the social function of education as education ontology, overwhelm the value of individual in education, hinder the play of individual talent and the development of personality, which in turn is distorting the social function of education.

Education summarizes the personality traits that pre-school children need to develop: confidence, independence, motivation, curiosity, perseverance, cooperation, selfdiscipline and caring for others.

"Modern education has its own laws, however, what kind of education development, there will be what kind of development path, development model and development strategy, education concepts will produce fundamental and overall significant influence to the development and practice of education." [5] The systematic analysis of modern preschool education concept is conducive to the further development of pre-school education concept and the development of pre-school education.

\section{REFERENCES}

[1] Sun Miantao. Reflections on Educational Concept, Education Theory and Practice, 1999(19), No. 4:2-9 
[2] Sun Miantao. Reflections on Educational Concept, Education Theory and Practice, 1999(19), No. 4:2-9

[3] Dewey, Chang Daozhi: Populism and Education, Commercial Press, 1922 Edition, Page 4
[4] Yu Yongping. New Theory on Children's Education Concept, People's Education Press, 2009 Edition, Page 49

[5] Lv Zhihe, Yan Fuqi. Research on Scientific Education Concept, Southwest Jiaotong University Press, 2013: Page 2 